\title{
DYNAMICS OF COMPETITIVENESS OF THE REGIONS IN BULGARIA
}

\author{
Iv. Ivanov* \\ Faculty of Business Management, University of Forestry, Sofia, Bulgaria
}

\begin{abstract}
Balanced development of regions is one of the European Union's goals. Region competitiveness is an approach used for assessing regional development and regional inequalities. The aim of the paper was to research the regions in Bulgaria by estimating their competitiveness and comparing the scores obtained with previous periods. A Regional Competitiveness Index (RCI) was designed on the basis of 10 indicators: population density per sq. km; natural growth; rate of employed persons; relative share of population aged between 25-64 with a higher education degree; foreign direct investment per capita in non-financial enterprises on cumulative basis; expenditure on acquisition of tangible fixed assets; productivity; turnover per capita; gross domestic expenditure on research and development per person engaged in research and development, and relative share of people aged between 16-74 years who have used the internet in the last 12 months. The period of research was 2004-2015, and it confirmed the leading role of Sofia (capital) district. At the bottom of the ranking scale, the less competitive regions were Vidin, Montana, Kardzhali, Silistra, Kyustendil, Smolyan, Razgrad, Targovishte and Yambol. Recommendations were made for improving the competitiveness of the underdeveloped regions.
\end{abstract}

Key words: regional development, regional inequalities, regional competitiveness index (RCI).

\section{INTRODUCTION}

Balanced development of regions is one of the European Union goals. Region competitiveness is an applicable approach for assessing regional development and regional inequalities. According to Dijkstra et al., regional competitiveness is the ability of a region to offer an attractive and sustainable environment for firms and residents to live and work (1). Studies of Ivanova et al, Navickas et al., Judrupa et al., Kamola et al., Kamols, Kamols et al., Kirsanov et al., Tambovcheva et al. research the theory and practice of regional competitiveness, its role and importance for evaluation of regional development (2-11).

The EU has designed an analytical measure for observation of development of NUTS (Nomenclature of Territorial Units for Statistics) 2 level regions in the community. It is based on 11 pillars: regional and national institutions, macroeconomic stability, infrastructure, health, basic education, higher education and lifelong learning, labour market efficiency, market size, regional technological readiness, business sophistication and

\footnotetext{
*Correspondence to: Ivaylo Ivanov, Faculty of Business Management, 10, St. Kliment Ohridski blvd., University of Forestry, Sofia, 1797, Bulgaria, ihivanov@hotmail.com
}

innovation (12). The results for Bulgaria are negative and all regions in Bulgaria are at the bottom of the ranking list. The information is applicable for comparing the regions in Bulgaria with other region in the EU but do not give information in detail that will be helpful for the government of Bulgaria.

Studies of Bojkov et al., Ganchev, Ivanov, Ivanova et al., Pashev, Nikolova et al. describe imbalances in the development of Bulgarian regions (districts and municipalities) from different points of view (13-22).

The aim of the present paper was to research the regions (districts) in Bulgaria by estimating their competitiveness and comparing the scores obtained with previous periods.

The main tasks were:

a) to calculate the RCI for 2015 by district and to rank the districts;

b) to compare the districts by RCI with previous years;

c) to analyse the districts' ranking for the period of 2004-2015 and to analyse the ranking variation.

The objects of research were the regions (districts) of Bulgaria, which correspond to NUTS 3 level of Eurostat. The period of 
research was 2004-2015. The data were obtained from the National Statistical Institute.

\section{METHODS}

Competitiveness of the districts in Bulgaria was estimated using the Regional Competitiveness Index (RCI) which was designed on the basis of 10 indicators:

a) population density per sq. $\mathrm{km}$;

b) natural growth, \%;

c) rate of employed persons \%;

d) relative share of population aged between 25-64 with a higher education degree, \%;

e) foreign direct investment per capita in nonfinancial enterprises on cumulative basis;

f) expenditure on acquisition of tangible fixed assets, thousand BGN;

g) productivity, BGN per employed person;

h) turnover per capita;

i) gross domestic expenditure on research and development per person engaged in research and development;

j) relative share of people aged between 1674 years who have used the internet in the last 12 months, $\%$.

The indicators assess four key spheres of regional development. These are market size, quantity and quality of labour resources, region attractiveness and competitiveness of local businesses. The indicators were selected on the basis of their representativeness and reliability. Some of them were obtained by additional calculations using the official statistical data.

Estimating the RCI was made by using a known mathematical statistical methodology,

$$
z_{i j}=\frac{x_{i j}-\bar{x}_{i}}{\sigma_{i}}, \quad i=1,2, \ldots, n,
$$

where $z_{i j}$ is the standardised deviation of $\mathrm{i}^{\text {th }}$ indicator of $\mathrm{j}^{\text {th }}$ district;

$x_{i j}$ - value of $\mathrm{i}^{\text {th }}$ indicator of $\mathrm{j}^{\text {th }}$ district;

$\bar{x}_{i}$ - arithmetic average of $\mathrm{i}^{\text {th }}$ indicator calculated by

$\bar{x}_{i}=\frac{\sum_{j=1}^{m} x_{i j}}{m}, \quad i=1,2, \ldots, n$;

$\sigma_{i}-$ standard deviation of $\mathrm{i}^{\text {th }}$ indicator

calculated by

$\sigma_{i}=\sqrt{\frac{\sum_{j=1}^{m}\left(x_{i j}-\bar{x}_{i}\right)^{2}}{m}}, \quad i=1,2, \ldots, n$. which eliminated the difficulties and inconveniences of different indicator measurements. All indicators have same relative weight in the RCI and the max indicator value means the best value.

The methodology used examines each district as a vector whose coordinates are numerical characteristics of selected indicators. The algorithm allows including an unlimited number of indicators regardless of the unit in which they are represented. The dependent $n$ indicators and $m$ districts can be represented by $n * m$ measurement matrix.

$$
x=\left(\begin{array}{cccc}
x_{11} & x_{12} & \ldots & x_{1 m} \\
x_{21} & x_{22} & \ldots & x_{2 m} \\
\ldots & \ldots & \ldots & \ldots \\
x_{n 1} & x_{n 2} & \ldots & x_{n m}
\end{array}\right)
$$

A hypothetical district, called standard district or the best district, is defined as a vector having the best values for each indicator of the compared districts. Each district is compared with the standard district. The final district assessment (score) is the aggregation of the distances to the standard district for each indicator.

The steps of the methodology are (23-26):

1. Calculating the standardised deviation of indicators (i) for different regions (j) of the arithmetical average of each indicator in order to avoid differences in their scale.

$$
j=1,2, \ldots, m,
$$

2. Establishing a Z-matrix using standardized indicators $z_{i j}$ and determining the standard istrict.

The obtained standardised indicator $z_{i j}$ in every line is a vector whose total sum of coordinates equals to zero, but the length of the vector equals to 1 . This matrix is used to calculate the final assessment and it is similar to the distance method. The standard district in this case is determined by Z-matrix values. This is the vector having the best values $z_{i j}$ for each indicator $i$. When the indicator should have a maximum value (a positive indicator, e.g. GDP), the maximum value of $z_{i j}$ is chosen, and when the indicator should have a minimum value (a negative indicator, e.g. 
unemployment rate), the minimum value of $z_{i j}$ is chosen.

3. Calculating the final assessment (score).

$$
R C I_{j}=\sqrt{\sum_{i=1}^{n}\left(z_{i j}-z_{i m}\right)^{2}}, j=1,2, \ldots, m,
$$

where $R_{j}$ is the final assessment for $\mathrm{j}^{\text {th }}$ district;

$z_{i j}$ - standardised deviation of $\mathrm{i}^{\text {th }}$ indicator of $\mathrm{j}^{\text {th }}$ district;

$z_{\text {im }}$ - standardised deviations of $\mathrm{i}^{\text {th }}$ indicator of standard district.

The RCI represents the distance between a given district and the standard district. The most competitive districts have the lowest RCI score, which means they are closer to the standard district. The less competitive districts have higher RCI scores, which means they are farther from the standard district.

\section{RESULTS AND DISCUSSIONS}

The RCI for 2015 shows (Table 1):

- Sofia (capital) district is at the top of the ranking list with a score of 5.506, which is twice as high as that of the second best district.

- The districts having the major cities in Bulgaria as administrative centres occupy the top places of the 2015 ranking list. These are Varna $\left(2^{\text {nd }}\right.$ place $)$, Burgas $\left(3^{\text {rd }}\right.$ place), Plovdiv ( $4^{\text {th }}$ place $)$, Sofia $\left(5^{\text {th }}\right.$ place $)$ and Stara Zagora $\left(6^{\text {th }}\right.$ place). The scores are from 11.001 (Varna) to 12.091 (Stara Zagora).

- The group of the top 10 districts by competitiveness includes also: Smolyan ( $7^{\text {th }}$ place), Ruse $\left(8^{\text {th }}\right.$ place $)$, Blagoevgrad $\left(9^{\text {th }}\right.$ place) and Gabrovo ( $10^{\text {th }}$ place $)$. The difference in scores in comparison to the previous districts is insignificant. The scores are as follows: 11.092 for Smolyan, 12.329 for Ruse, 12.793 for Blagoevgrad and 12.835 for Gabrovo.

- Districts of Veliko Turnovo, Pleven, Shumen, Yambol, Pazardzhik, Dobrich, Pernik, Sliven, Lovech and Haskovo hold places from $11^{\text {th }}$ to $20^{\text {th }}$ in the ranking list. These districts can be defined as districts with moderate competitiveness. The scores are from 12.919 for Veliko Turnovo to 13.636 for Haskovo.

- The bottom places of the ranking list are occupied by the following districts: Vratza $\left(21^{\text {st }}\right.$ place $)$, Razgrad ( $22^{\text {nd }}$ place $)$, Kardzhali $\left(23^{\text {rd }}\right.$ place $)$, Kyustendil $\left(24^{\text {th }}\right.$ place), Silistra $\left(25^{\text {th }}\right.$ place $)$, Vidin $\left(26^{\text {th }}\right.$
The final district assessment is the aggregation of the distances to the standard district for each indicator and it is calculated by the formula place), Montana $\left(27^{\text {th }}\right.$ place $)$ and Turgovishte $\left(28^{\text {th }}\right.$ place). This is the group of less competitive districts.

- Six of the 8 less competitive districts are in North Bulgaria. Although the number of districts with moderate competitiveness is the same in North and South Bulgaria, a significant difference is observed in the number of most competitive districts. The proportion is 3 to 7 , in favour to South Bulgaria.

The results indicate that Sofia (capital) district disturbs the homogeneity of the group and should be excluded from the statistical aggregation. However, previous studies have shown that estimating the RCI with Sofia (capital) district and without it did not affect the ranking significantly (27).

Table 1. RCI in 2015

\begin{tabular}{|l|l|l|l|}
\hline Place & District name & District code & Score \\
\hline
\end{tabular}

\begin{tabular}{|l|l|l|l|}
\hline 1 & Sofia (capital) & SOF & 5.506 \\
\hline 2 & Varna & VAR & 11.001 \\
\hline 3 & Burgas & BGS & 11.377 \\
\hline 4 & Plovdiv & PVD & 11.378 \\
\hline 5 & Sofia & SFO & 11.608 \\
\hline 6 & Stara Zagora & SZR & 12.091 \\
\hline 7 & Smolyan & SML & 12.092 \\
\hline 8 & Ruse & RSE & 12.329 \\
\hline 9 & Blagoevgrad & BLG & 12.793 \\
\hline 10 & Gabrovo & GAB & 12.835 \\
\hline 11 & Veliko & VTR & 12.919 \\
\hline 12 & Purnovo & & \\
\hline 13 & Sheven & PVN & 13.025 \\
\hline 14 & Yambol & SHU & 13.068 \\
\hline 15 & Pazardzhik & PAM & 13.089 \\
\hline 16 & Dobrich & DOB & 13.129 \\
\hline 17 & Pernik & PER & 13.378 \\
\hline 18 & Sliven & SLV & 13.480 \\
\hline 19 & Lovech & LOV & 13.482 \\
\hline 20 & Haskovo & HKL & 13.636 \\
\hline 21 & Vratza & VRC & 13.672 \\
\hline 22 & Razgrad & RAZ & 13.681 \\
\hline 23 & Kardzhali & KRZ & 13.799 \\
\hline 24 & Kyustendil & KNL & 13.882 \\
\hline 25 & Silistra & SLS & 14.365 \\
\hline 26 & Vidin & VID & 14.412 \\
\hline 27 & Montana & MON & 14.493 \\
\hline 28 & Targovishte & TGV & 14.527 \\
\hline & & & \\
\hline
\end{tabular}


When comparing the 2014 ranking list with the 2015 list, some significant changes in district competitiveness (Table 2) have been identified.

Smolyan has improve its competitiveness with 12 places: from $19^{\text {th }}$ place in 2014 it holds $7^{\text {th }}$ place in 2015. Pleven has also moved up, increasing its competitiveness by 5 places. One district (Sliven) goes up in the ranking list with 3 places, from $21^{\text {th }}$ to $18^{\text {th }}$ place. Three districts go up with 2 places - Veliko Turnovo from $13^{\text {th }}$ to the $11^{\text {th }}$ place, Silistra from $27^{\text {th }}$ to $25^{\text {th }}$ place and Vidin from $28^{\text {th }}$ to $26^{\text {th }}$ place.

A drop in the rankings with 6 places has been observed for the following districts: Pazardzhik (from $9^{\text {th }}$ place in 2014 to $15^{\text {th }}$ place in 2015) and Haskovo (from $14^{\text {th }}$ place in 2014 to $20^{\text {th }}$ place in 2015). Razgrad falls in the ranking list with 4 places (from $18^{\text {th }}$ to $22^{\text {nd }}$ place). Six districts move down with 2 places Sofia (from $3^{\text {rd }}$ to $5^{\text {th }}$ place), Gabrovo (from $8^{\text {th }}$ to $10^{\text {th }}$ place), Shumen (from $11^{\text {th }}$ to $13^{\text {th }}$ place), Yambol (from $12^{\text {th }}$ to $14^{\text {th }}$ place), Montana (from $25^{\text {th }}$ to $27^{\text {th }}$ place) and Targovishte (from $26^{\text {th }}$ to $28^{\text {th }}$ place).

Three districts have maintained their places in the ranking list in 2015 in comparison with 2014 - Sofia (capital) ( $1^{\text {st }}$ place), Varna $\left(2^{\text {nd }}\right.$ place) and Stara Zagora ( $6^{\text {th }}$ place) .

The remaining 10 districts have changed their ranking with 1 place. Six of them have improved their competitiveness - Burgas (from $4^{\text {th }}$ to $3^{\text {rd }}$ place), Plovdiv (form $5^{\text {th }}$ to $4^{\text {th }}$ place), Blagoevgrad (from $10^{\text {th }}$ to $9^{\text {th }}$ place), Lovech (from $20^{\text {th }}$ to $19^{\text {th }}$ place), Vratza (from $22^{\text {nd }}$ to $21^{\text {st }}$ place) and Kardzhali (from $24^{\text {th }}$ to $23^{\text {rd }}$ place), and 4 districts have fallen in the ranking Ruse (from $7^{\text {th }}$ to $8^{\text {th }}$ place), Dobrich (from $15^{\text {th }}$ to $16^{\text {th }}$ place), Pernik (from $16^{\text {th }}$ to $17^{\text {th }}$ place) and Kyustendil (from $23^{\text {rd }}$ to $24^{\text {th }}$ place).

Table 2. Place of districts by RCI and by year

\begin{tabular}{|l|l|l|l|l|l|l|l|l|l|l|l|l|}
\hline Districts & $\mathbf{2 0 1 5}$ & $\mathbf{2 0 1 4}$ & $\mathbf{2 0 1 3}$ & $\mathbf{2 0 1 2}$ & $\mathbf{2 0 1 1}$ & $\mathbf{2 0 1 0}$ & $\mathbf{2 0 0 9}$ & $\mathbf{2 0 0 8}$ & $\mathbf{2 0 0 7}$ & $\mathbf{2 0 0 6}$ & $\mathbf{2 0 0 5}$ & $\mathbf{2 0 0 4}$ \\
\hline SOF & 1 & 1 & 1 & 1 & 1 & 1 & 1 & 1 & 1 & 1 & 1 & 1 \\
\hline VAR & 2 & 2 & 3 & 5 & 4 & 2 & 2 & 2 & 2 & 2 & 3 & 2 \\
\hline BGS & 3 & 4 & 2 & 2 & 3 & 3 & 3 & 3 & 3 & 3 & 2 & 3 \\
\hline PVD & 4 & 5 & 4 & 3 & 5 & 5 & 4 & 6 & 6 & 6 & 7 & 6 \\
\hline SFO & 5 & 3 & 5 & 4 & 2 & 4 & 7 & 4 & 4 & 4 & 4 & 4 \\
\hline SZR & 6 & 6 & 7 & 6 & 6 & 6 & 5 & 7 & 5 & 5 & 6 & 5 \\
\hline SML & 7 & 19 & 18 & 22 & 27 & 22 & 19 & 10 & 22 & 21 & 25 & 12 \\
\hline RSE & 8 & 7 & 6 & 7 & 7 & 7 & 6 & 8 & 9 & 8 & 12 & 11 \\
\hline BLG & 9 & 10 & 10 & 11 & 10 & 13 & 14 & 5 & 7 & 7 & 5 & 7 \\
\hline GAB & 10 & 8 & 8 & 9 & 8 & 8 & 8 & 20 & 21 & 14 & 9 & 14 \\
\hline VTR & 11 & 13 & 13 & 14 & 13 & 11 & 13 & 9 & 8 & 11 & 11 & 9 \\
\hline PVN & 12 & 17 & 14 & 19 & 20 & 19 & 16 & 16 & 19 & 10 & 8 & 8 \\
\hline SHU & 13 & 11 & 12 & 15 & 17 & 16 & 15 & 14 & 18 & 25 & 14 & 23 \\
\hline JAM & 14 & 12 & 9 & 8 & 12 & 18 & 17 & 18 & 15 & 16 & 16 & 13 \\
\hline PAZ & 15 & 9 & 19 & 17 & 15 & 15 & 21 & 13 & 16 & 13 & 13 & 15 \\
\hline DOB & 16 & 15 & 15 & 12 & 18 & 12 & 20 & 17 & 20 & 12 & 19 & 22 \\
\hline PER & 17 & 16 & 17 & 10 & 9 & 14 & 10 & 12 & 10 & 19 & 15 & 18 \\
\hline SLV & 18 & 21 & 16 & 21 & 16 & 23 & 11 & 21 & 14 & 18 & 20 & 17 \\
\hline LOV & 19 & 20 & 23 & 23 & 11 & 10 & 12 & 15 & 12 & 9 & 10 & 10 \\
\hline HKV & 20 & 14 & 11 & 13 & 14 & 9 & 9 & 11 & 13 & 17 & 17 & 21 \\
\hline VRC & 21 & 22 & 20 & 20 & 19 & 17 & 18 & 22 & 11 & 15 & 23 & 19 \\
\hline RAZ & 22 & 18 & 21 & 18 & 21 & 24 & 23 & 27 & 25 & 24 & 22 & 20 \\
\hline KRZ & 23 & 24 & 26 & 27 & 28 & 28 & 28 & 26 & 26 & 26 & 21 & 24 \\
\hline KNL & 24 & 23 & 22 & 26 & 23 & 21 & 24 & 23 & 23 & 22 & 24 & 25 \\
\hline SLS & 25 & 27 & 28 & 24 & 25 & 26 & 26 & 24 & 27 & 27 & 26 & 16 \\
\hline VID & 26 & 28 & 27 & 28 & 26 & 27 & 27 & 28 & 28 & 28 & 28 & 28 \\
\hline MON & 27 & 25 & 25 & 25 & 24 & 25 & 25 & 25 & 24 & 23 & 27 & 26 \\
\hline TGV & 28 & 26 & 24 & 16 & 22 & 20 & 22 & 19 & 17 & 20 & 18 & 27 \\
\hline
\end{tabular}

The analysis of a district place variation by RCI allows drawing several general conclusions (Figure 1).
First, Sofia (capital) district during the whole period of 2004-2015 never changed its place. Its leader's place is incontestable. The leadership position of Sofia (capital) district cannot lend itself to simple assessment. On the 
one hand, Sofia (capital) is the district where the political and administrative governance of the country is located, where most universities and research institutes and organizations are situated, and it is understandable that Sofia (capital) is the most competitive region. On the other hand, the concentration of human, intellectual, administrative and management capital is attractive for local and foreign entrepreneurs and investors, which widens the labour market, motivates migration from other regions, eventually placing regional development into the spiral where Sofia (capital) district becomes more and more competitive and most of the other regions lose their competitiveness.

Second, 8 districts (Burgas, Vidin, Stara Zagora, Varna, Montana, Plovdiv, Kyustendil and Sofia) have changed their competitiveness ranking with up to 5 places: 5 of them are districts with high competitiveness (Burgas, Stara Zagora, Varna, Plovdiv and Sofia) and 3 of them are less competitive districts (Vidin, Montana and Kyustendil). That shows stable competitive positions for some districts and stable noncompetitive positions for other districts. The results are of great concern, and indicate that regions at the bottom of the ranking list cannot improve and increase their competitiveness. They are persistent in keeping their noncompetitiveness and disadvantages.

Third, half of the districts have very changeable competitiveness. Their ranking variation is more than 10 positions. Smolyan is the leader in this aspect because it changed its competitiveness with 22 places. In the same group are Lovech, Shumen, Gabrovo, Vriatsa, Razgrad, Pleven, Silistra, Sliven, Targovishte, Haskovo, Dobrich, Yambol and Pernik. The presence or absence of ranking variation cannot be simply described as positive or negative. Very important is the direction of change: increase or decrease in competitiveness. If a district improves its competitiveness, moving up the list, then the change is positive. It can also be evaluated as positive, if a district maintains its competitiveness and there is not change of its place in the rankings. But if a district falls into the ranking list, then definitely this is negative situation. The change in the ranking list is a motivator, source and challenge for regional governance to maintain or to improve the score and the rank. But the huge jumps/falls are a signal for instability of the region. This can discourage or scare investors and entrepreneurs.

Fourth, there are 5 districts that changed their position by RCI between 5 and 10 places: Blagoevgrad, Pazardzhik, Kardzali, Veliko Turnovo and Ruse.

The reason for the observed significant ranking variation results from the choice of indicators. For some years there were not data for some districts mainly for the foreign direct investment per capita in non-financial enterprises on cumulative basis and for gross domestic expenditure on research and development per person engaged in research and development because of data confidentiality or no registered cases.

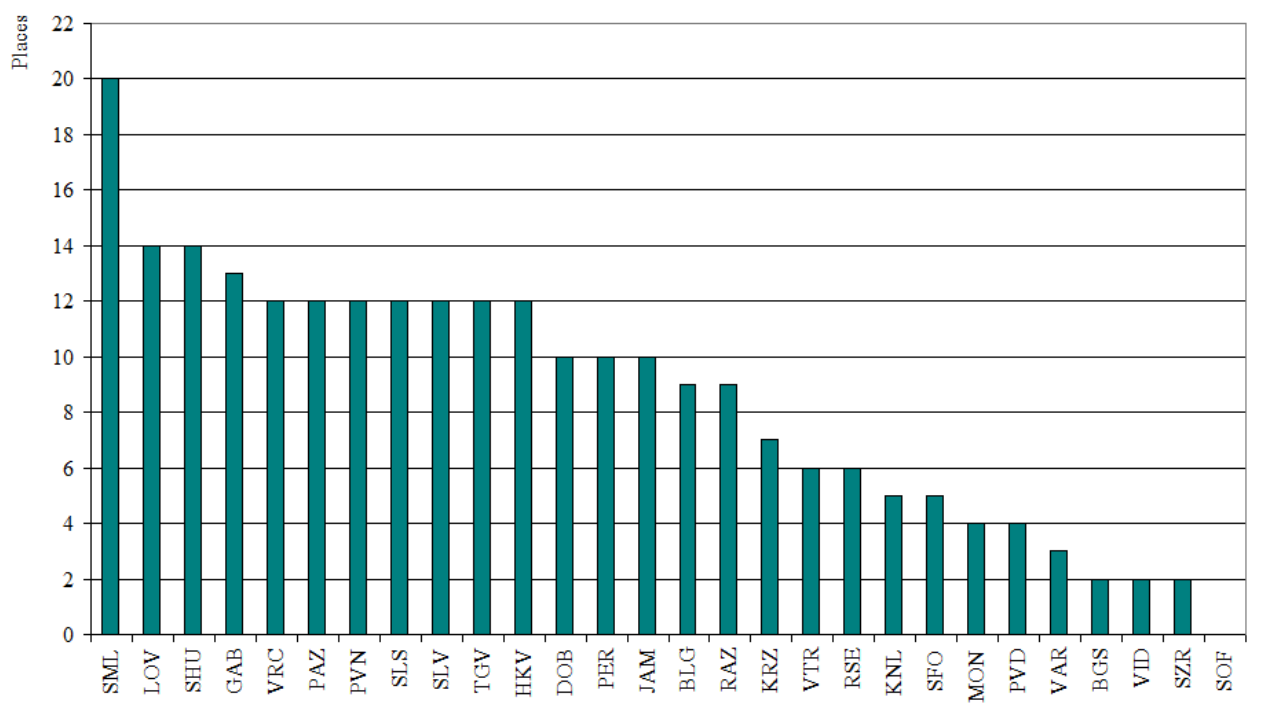

Figure 1. Range of district ranking variation for 2004-2015

The RCI allows analysing the direction of change in the ranking list.

For the whole observed period from 2004 to 2015, Sofia (capital) district, as shown above, never changed its position in the ranking list (Figure 2). Sofia (capital) is the leader, the 'motor' of Bulgarian economy, the most competitive region in the country for 11 
consecutive years. The other relatively stable regions are Burgas, which kept its position in the ranking list 6 times, Varna and Vidin, which kept their positions in the ranking list 5 times, Sofia, Stara Zagora, Kardzhali and Montana, which kept their positions in the ranking list 4 times. These results are a cause for concern. They show that the most competitive district, Sofia (capital), is impossible to be displaced from the first place. Its role in the economy is undisputed. Burgas,
IVANOV IV.

also one of the most competitive districts, was 6 times at the same place in the ranking list. On the other hand, Vidin, which is one of the less competitive districts, did not change its place 5 times. Montana is another district at the bottom of ranking list, which relatively rarely changed its places. On the basis of these results, it can be concluded that the most competitive and the less competitive districts are hard to change their respective places.

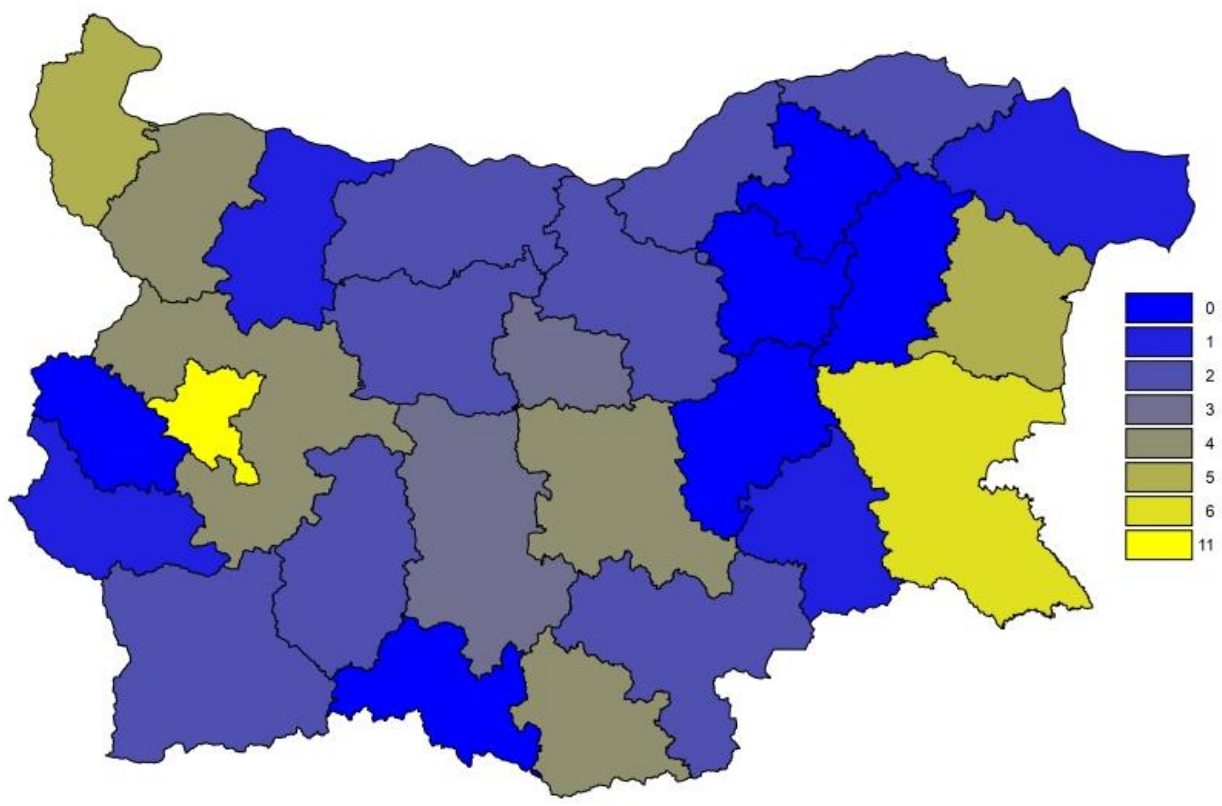

Figure 2. Number of years with maintained ranking

The districts that most often improved their competitiveness are Blagoevgrad, Haskovo, Shumen and Sliven which increased their ranking 6 times; 5 times this was achieved by Vratsa, Lovech, Silsistra, Dobrch, Kyustendil, Smolyan and Kardzhali (Figure 3).

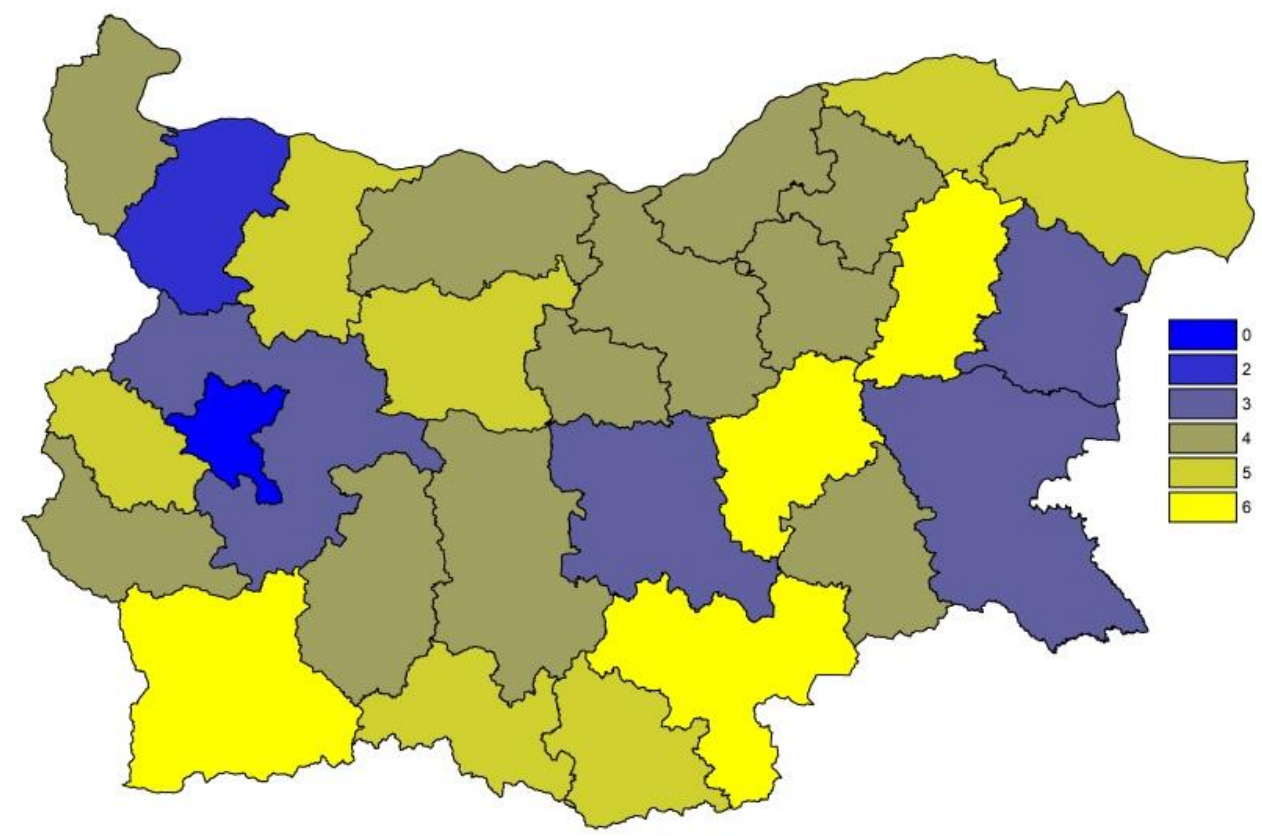

Figure 3. Number of years with better ranking

The districts that most often lost their competitiveness are Razgrad and Targovishte
(7 times); 6 times this happened with Kyustendil, Pernik, Smolyan and Yambol; 5 


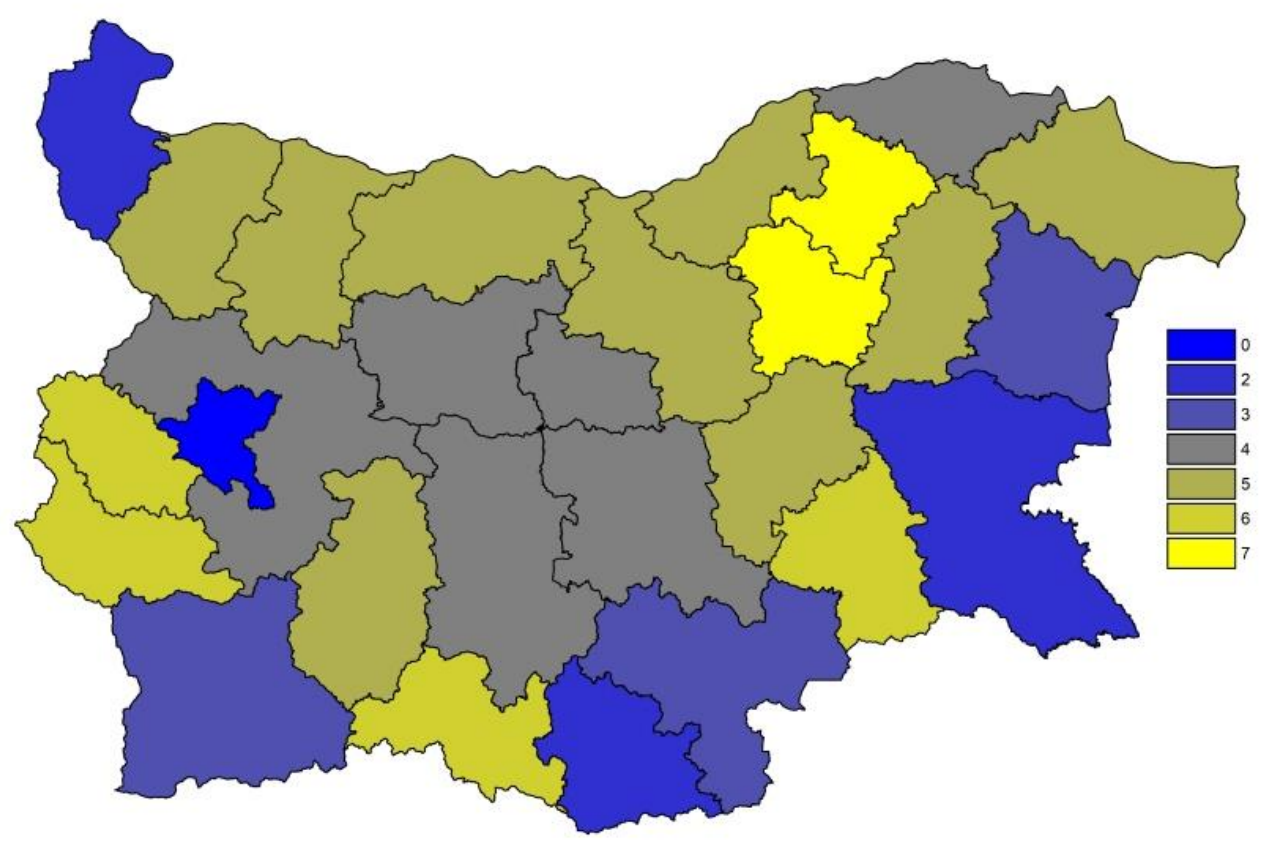

Figure 4. Number of years with worse ranking

A 'gold' standard for ranking variation is hard to define. It would be very stimulating and motivating, if all regions, at given periods of time, were at the top or at the bottom of the ranking list, i.e. when at the top, a region will make efforts to maintain its competitiveness, and when at the bottom - to improve it. The challenges are 'Is it possible to do this on one's own, without government support?' and 'How can a region improve its poor rating?'. The RCI gives the answer to the first question and it is simple - 'No, it is impossible in Bulgaria'. For twelve years, from 2004 to 2015, Vidin, Kardzhali, Montana, Kyustendil and Silistra very often occupied the bottom of the ranking list and never took a place higher than $21^{\text {st }}$ with one exception for Silistra in 2004. The second question has no universal solution. Possible approaches, often pointed by experts and politicians, are: stimulating investments in these less competitive districts and developing innovative economic sectors, creating conditions for re-locating businesses, which can help decreasing and halting depopulation, providing education for improving the skills of the labour force. The financial sources for these measures can be flexible, using the EU funds. Additional studies are necessary to analyse the role of the government during the EU programming periods. Regional competitiveness can be improved if the government is focused on supporting the correct identification of local problems, developing competitive projects, efficient and effective management these projects and ensuring conditions for sustainable post-project development. Key factors for competitiveness improvement are foreign direct investment per capita in non-financial enterprises on cumulative basis and the gross domestic expenditure on research and development per person engaged in research and development, which is confirmed by the scores of Smolyan district.

\section{CONCLUSIONS}

The observed situation in dynamics of districts development from 2004 to 2015 showed:

- a significant difference between Sofia (capital) and the other districts in Bulgaria,

- a significant difference between North and South Bulgaria;

- establishment of a new problem region in Bulgaria - North-East, including Silistra and Razgrad districts;

- continuation of the processes characterized by backwardness of development and deepening inequality in the districts in North-West Bulgaria, mainly in Vidin, Montana and Vratsa districts;

- relatively stable groups of most competitive and most non-competitive districts;

- the less competitive districts are Vidin, Montana, Kardzhali, Silistra, Kyustendil, Smolyan, Razgrad, Targovishte and Yambol.

\section{REFERENCES}

1. Dijkstra, L., Annoni P., Kozovska, K. A new European Regional Competitiveness Index: theory, methods and findings. DG 
Regional Policy Working Papers, WP 02/2011, 2011.

2. Ivanova, S., Kamola, L., Kamols, U. Impact of Economic Activity on Regions in Latvia. XI International Scientific Conference "Management and Engineering'13", Bulgaria, Sozopol, pp. 844-852. 2013.

3. Navickas, V.; Malakauskaite, A. Methodological problems and limitations of competitiveness evaluation. Business: Theory and Practice/Verslas: Teorija ir Praktika, 11.1, pp. 5-11. 2011.

4. Judrupa, I., Bērziņa, I. Role of Innovations in the Increasing of Regional Competitiveness in Latvia. Management and Sustainable Development, 2 (51), pp. 19-23, 2015.

5. Judrupa, I., Senfelde, M. Application of the Ranking Method in the Evaluation of Regional Competitiveness in Latvia. Economic Research in Business, 17, pp. 3745, 2008.

6. Judrupa, I., Senfelde, M. Competitiveness of Planning Regions in Latvia. Management and Sustainable Development, 2(26), pp. 15-18, 2010.

7. Kamola, L., Ivanova, S., Kamols, U. Trends of Regional Development in Latvia - Aspect of Human Resource. Proceedings of $13^{\text {th }}$ Research World International Conference, Singapore, 4 March, 2016, pp. 21-25, 2016.

8. Kamols, U. Impact of European Union Structural Funds on Increase of Competitiveness of Latvian Cities. 50. RTU Starptautiska zinatniska konference: RTU IEVF Ekonomikas un uznemejdarbibas zinatniska konference (SCEE' 2009): konferences zinojumu tezu krajums, Latvia, Riga, 15-16 October, 2009, Rīga: RTU Izdevnieciba, pp. 55-56, 2009.

9. Kamols, U., Ivanova, S., Kamola, L. Industrial Development Latvia and its Major Cities and Towns. XII International Scientific Conference „Management and Engineering '14": Conference Proceedings. Vol.2, Bulgaria, Sozopol, 22-25 June, 2014, pp. 1026-1035, 2014.

10.Kirsanov, S., Safonov, J., Kamola, L., Kamols, U., Stamure, I., Survilo, T., Judrupa, I., Blagova, G., Gorbunova, K., Senfelde, M. Capital repair of housing stock in the period of housing and communal services reform. Moscow, Elit Publishing House, 2015, (in Russian).

11.Tambovceva, T., Tambovcevs, A. Competitiveness of Nano Technology, Advanced Materials Research, 1079-1080, pp. 1142-1148, doi:10.4028/www.scientific.net/AMR.1079 $-1080.1142,2015$.
12.Annoni, P., Dijkstra, L., Gardano, N. The EU Regional Competitiveness Index 2016. DG Regional and Urban Policy Working Papers, WP 02/2017, doi:10.2776/94425, 2017.

13.Bojkov, A., Ivanovski D., Damyanova, A. Competitiveness of Bulgarian Economy: Annual Report 2001. Center for Economic Development, Sofia, 2002.

14.Gancev, G. The competitive advantages of the regions. Creating Competitive Clusters in the Bulgarian Economy: Factors, Perspectives and Strategies. Institute for Market Economics, Open Society Publishing, Sofia, 1999, (in Bulgarian).

15.Ivanov, I. Evaluation of the competitiveness at the local level. Conference Proceedings, The $5^{\text {th }}$ International Scientific Conference "Business and Management 2008", VGTU, Vilnius. 16-17.05.2008, Vilnius, Lithuania, (CD), 2008.

16.Ivanov, I. Index of Competitiveness of the region in Bulgaria. Selected paper. volume II. The 6th International Scientific Conference "Business and Management 2010", VGTU Publishing House "Technika", 13-14.05.2010, Vilnius, Lithuania, pp. 619-626, 2010.

17.Ivanova, D., Stoenchev, N., Ivanov, I., Delijska, B., Popova, P., DragozovaIvanova, E. Competitiveness of furniture enterprises in Bulgaria, Avangard Prima Publishing House, Sofia, 2010, (in Bulgarian).

18.Ivanova, D., Stoenchev, N., Kovacheva, S., Ivanov, I. Studying of competitiveness of the furniture enterprises in Bulgaria. Scientific-Technical Conference on Innovation in woodworking industry and engineering design. Proceeding of scientific papers. November 14-16, 2008, Yundola, Bulgaria. Avangard Prima Publishing House, Sofia, pp. 126-130, 2009, (in Bulgarian).

19.Ivanova, D., Stoenchev, N., Kovacheva, S., Ivanov, I., Kostadinov, A. Competitiveness of the furniture industry, Avangard Prima Publishing House, Sofia, 2010, (in Bulgarian).

20.Pashev, K. Competitiveness of the Bulgarian Economy, BNB, Sofia, 2003.

21.Nikolova, D., Tsvetkov, A., Ganev, P., Aleksiev, A., Slavova, Z. The Regional Profiles. Indicators of Development. Institute for Market Economics, Sofia, 2015.

22.Nikolova, D., Tsvetkov, A., Ganev, P., Aleksiev, Y., Slavova, Z. Regional Profiles: Indicators for Development. Institute for Market Economy, Sofia, 2016. 
23.Gatev, K. Introduction to statistics. LIA Publishing House, Sofia, 1995, (in Bulgarian).

24.Stoenchev, N. Possibilities for application of statistical methods in studying the company's competitiveness. Avangard Prima Publishing House, Sofia, 2010, (in Bulgarian).

25.Stoenchev, N. Quality of life and specialization of the territory by economic activities in Bulgaria (statistical aspects).
Intel Entrance Publishing House, Sofia, 2016, (in Bulgarian).

26. Stoenchev, N., Ivanov, I. Manual with solved and unsolved problems in statistics (with application of EXCEL). University of Forestry, Sofia, 2015, (in Bulgarian).

27.Ivanov, I. Economic problems of depressed regions in Bulgaria. Dissertation, University of Forestry, Sofia, 2016, (in Bulgarian). 